\title{
Market and supplier characteristics driving distributor relationship quality in international marketing channels of industrial products
}

\author{
Dionysis Skarmeas $^{\text {a }}$, Constantine S. Katsikeas ${ }^{\text {b,* }}$, Stavroula Spyropoulou ${ }^{\text {b }}$, Esmail Salehi-Sangari ${ }^{\text {c }}$ \\ ${ }^{\text {a }}$ Department of Industrial Management \& Technology, University of Piraeus, 107 Deligiorgi Street, Piraeus 185 34, Greece \\ ${ }^{\mathrm{b}}$ Leeds University Business School, Maurice Keyworth Building, Leeds University, Leeds LS2 9JT, UK \\ ${ }^{\mathrm{c}}$ Industrial Marketing and e-Commerce Research Group, Lulea University of Technology, Regnbagsallen Porson, Lulea SE-971 87, Sweden
}

Received 15 September 2006; received in revised form 25 April 2007; accepted 30 April 2007

Available online 22 October 2007

\begin{abstract}
Although we are beginning to comprehend the fundamental importance of relationship quality in interorganizational exchange, a relatively small, but growing, body of literature that has not kept pace with the tremendous growth in global channel transactions has been devoted to the development of cross-border relationship quality. This study addresses this gap in the literature by investigating the extent to which certain market and exporter characteristics affect the development of relationship quality in the context of importing distributors trading with exporting manufacturers of industrial products. Relationship quality is viewed as a higher-order construct composed of trust, commitment, and satisfaction. Findings reveal that psychic distance is related negatively to relationship quality, while transaction-specific investments and role performance are associated positively with relationship quality. No link is found between environmental uncertainty and relationship quality. Managerial implications of the findings are considered and limitations along with future research directions discussed.
\end{abstract}

(C) 2007 Elsevier Inc. All rights reserved.

Keywords: Relationship quality; International marketing channels; Industrial marketing

\section{Introduction}

A basic tenet of relationship marketing is that firms may successfully compete in the marketplace through developing cooperative relationships with selected key partners (Morgan \& Hunt, 1994; Sheth \& Parvatiyar, 1995). This practice is more evident in industrial (compared with consumer) markets, which is mainly due to the increased interdependencies between buyers and sellers and the reduced variety-seeking customer motivation (Cannon \& Perreault, 1999; Naude \& Buttle, 2000). The virtues of relationship marketing are widely espoused in this context by academics and practitioners alike. Extant research suggests close interfirm ties give rise to a variety of beneficial relational outcomes including enhanced trust, commitment, satisfaction, communication, cooperation, long-term orientation, and adaptation, as well as reduced decision-making uncertainty,

\footnotetext{
* Corresponding author. Tel.: +44 113 3432624; fax: +44 1133434885 .

E-mail address: csk@lubs.leeds.ac.uk (C.S. Katsikeas).
}

conflict, propensity to exit, and opportunism (e.g., Anderson, Hakansson, \& Johanson, 1994; Anderson \& Narus, 1990; Ganesan, 1994; Morgan \& Hunt, 1994).

In the relationship marketing literature, the issue of relationship quality has attracted considerable research attention. Relationship quality is an overarching construct composed of several key relational outcomes reflecting the overall nature of the exchange relationship (e.g., Dwyer, Schurr, \& Oh, 1987; Kumar, Scheer, \& Steenkamp, 1995). A rich and growing stream of studies highlight various advantages accruing for both selling and buying firms from forging high quality business relationships. For suppliers, they can engender greater customer retention (Hewett, Money, \& Sharma, 2002), serve as a pool of new leads, ideas, and experiences (Anderson \& Narus, 1991), and facilitate enhanced operational planning (Han, Wilson, \& Dant, 1993). For organizational customers, high quality relationships with suppliers can secure supply continuity (Sharma \& Sheth, 1997), bypass the risks associated with inaugurating new exchanges (Dorsch, Swanson, \& Kelley, 1998), result in the accommodation of special requirements (Bruggen, Kacker, 
$\&$ Nieuwlaat, 2005), and facilitate inventory reduction (Samiee \& Walters, 2006).

Despite theoretical claims and empirical evidence pointing to the critical role of relationship quality in the effective management of interfirm relationships in domestic settings (e.g., Bruggen et al., 2005; Dorsch et al., 1998; Dwyer et al., 1987), scant attention has been paid to relationship quality development in an international context (Leonidou, Barnes, \& Talias, 2006; Samiee \& Walters, 2003). This is unfortunate, given that growing liberalization of the world trade and intense domestic market competition have rendered global expansion activities increasingly important for the survival, growth, and success of modern firms (Morgan, Kaleka, \& Katsikeas, 2004). With increasing frequency, firms begin to realize that going international may no longer be one of their options, but rather an urgent necessity (Mehta, Larsen, Rosenbloom, \& Ganitsky, 2005). Further, most firms rely on cross-border business-tobusiness partnerships to enter overseas markets since it is a less difficult and risky foreign market entry mode that requires fewer capital and management resources than setting up joint ventures or subsidiaries overseas (Bello, Chelariu, \& Zhang, 2003; Cavusgil, 1998).

In addition, the limited research attention devoted to the study of relationship quality in cross-border marketing channels is surprising, considering that relationship quality building in an international context is more challenging compared to channel transactions in domestic settings. This is attributable primarily to the existence of differences in cultural, social, economic, political, technological, and allied factors between importing and exporting firms (e.g., Johanson \& Vahlne, 1990; Shoham \& Albaum, 1995; Stottinger \& Schlegelmich, 1998), along with the increased levels of uncertainty inherent in international operations (e.g., Akhter \& Robles, 2006; Czinkota \& Ronkainen, 2003; Erramilli, 1996). Unlike domestic market exchanges, trading partners in relationships that transcend national boundaries may be located anywhere in the world. The physical distance that commonly separates exchange partners makes personal visits and face-to-face contact difficult and expensive (Bello et al., 2003; Samiee \& Walters, 2006). Cultural, ethnic, and religious differences between trading partners may result in misunderstandings due to lack of a shared frame of reference (Barkema \& Vermeulen, 1997; Zhang, Cavusgil, \& Roath, 2003). Uncertainties associated with country-specific infrastructure and political and legal systems also inhibit the cultivation of close crossnational business relationships (Bello \& Zhu, 2006; Cavusgil, Deligonul, \& Zhang, 2004). These factors have important implications for the organization of cross-border channel relationships and decrease the likelihood and ability of international channel members to develop quality interactions with their foreign partners.

The aim of the present study is to investigate the factors that promote or forestall the development of relationship quality between an importing distributor and its foreign supplier. Specifically, certain market and exporter characteristics are posited to influence importers' perceptions of relationship quality. The contribution of this research is twofold: First, it considers the potentially important role that the international market char- acteristics of psychic distance and environmental uncertainty play in influencing relationship quality. Cross-border channel relationships not only face greater levels of environmental uncertainty (e.g., Erramilli 1996; Zhang et al., 2003), but encounter additional challenges such as differences in culture, accepted management styles and methods, and legal systems between the operating environments of the two parties (e.g., Kale \& Barnes, 1992; Samiee \& Walters, 2003) that are absent in a domestic setting. Thus, understanding the uniqueness of cross-border relationship building and how international market characteristics impinge on relationship quality is of great interest for international marketing theory and practice.

Second, our study focuses on the perspective of the importer, which is the neglected counterpart of the international exchange dyad (Liang \& Parkhe, 1997; Quintens, Pauwels, \& Matthyssens, 2006). As opposed to the scores of studies on exporting, there is a dearth of systematic research on firms' importing behavior (Ha, Karande, \& Singhapakdi, 2004; Katsikeas, 1998). This is striking, considering that: importers play a critical role in developing successful export ventures (e.g., Morgan et al., 2004); buyers and sellers may have perceptual differences regarding relational aspects (e.g., Wathne, Biong, \& Heide, 2001); and importing firms are the organizational customers of exporting suppliers and hence the ultimate decision-makers (cf. Cannon \& Perreault, 1999). Hence, this research adopts the importer's opinion of the cross-border channel relationship and studies variables that either refer to the importer (i.e., relationship quality), or that the importer could comfortably report on (i.e., environmental uncertainty and psychic distance and exporter role performance and transactionspecific investments). For brevity reasons we use the terms exporter role performance and transaction-specific investments, but explicitly acknowledge that they refer to the importer's perception of the exporter's role performance and transaction-specific investments.

The remainder of the article proceeds with an examination of the literature on relationship quality. For present purposes, relationship quality is defined as an importer's perception of higher levels of trust in, commitment to, and satisfaction with the exporter. Next, drawing on the internationalization, transaction cost, and power-dependence theories, market and exporter characteristics are discussed with regard to their impact on relationship quality. Briefly, we hypothesize that psychic distance and environmental uncertainty inhibit the development of relationship quality, while exporter role performance and transaction-specific investments enhance relationship quality (see Fig. 1). Then, the methodology adopted in this research is explained and the study results presented. Finally, the findings are discussed along with implications for international management and future research directions.

\section{Relationship quality}

Relationship quality is widely viewed as a metaconstruct made up of several components that support, reinforce, and complement each other (Dwyer et al., 1987). Although there has been considerable work on the conceptualization of relationship quality, the pertinent literature has not reached a general 


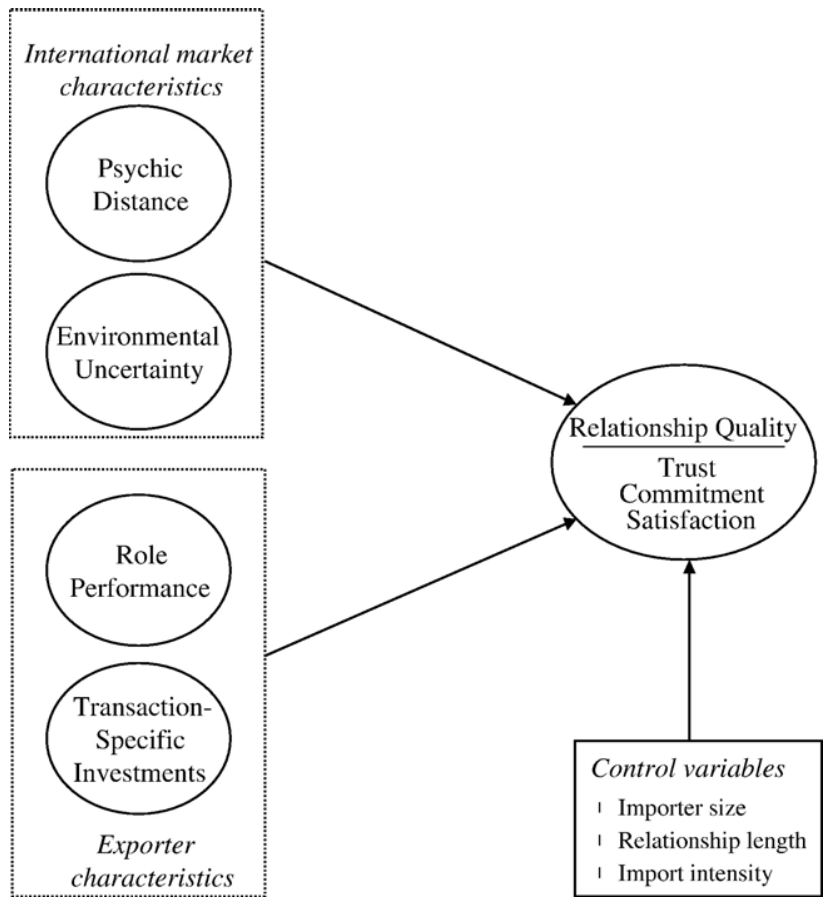

Fig. 1. Conceptual model.

consensus on its constituents (Bove \& Johnson, 2001; Naude \& Buttle, 2000). Prior research has proposed a variety of relationship quality dimensions, such as customer orientation, ethical profile, and forbearance from opportunism (Dorsch et al., 1998), minimal conflict, willingness to invest, and expectations of continuity (Jap, Manolis, \& Weitz, 1999; Kumar et al., 1995), information sharing, communication, and long-term orientation (Lages, Lages, \& Lages, 2005), fairness and cooperation (Johnson \& Raven, 1996), and adaptation and understanding (Leonidou et al., 2006).

However, trust, commitment, and satisfaction are given the pride of place among the factors that constitute relationship quality (e.g., Crosby, Evans, \& Cowles, 1990; Henning-Thurau, Gwinner, \& Gremler, 2002; Hewett et al., 2002; Hibbard, Kumar, \& Stern, 2001; Kumar et al., 1995). Specifically, a rich stream of research views relationship quality as a combination of some or all of these constructs (e.g., Bruggen et al., 2005; Farrelly \& Quester, 2005; Walter, Muller, Helfert, \& Ritter, 2003; Ulaga \& Eggert, 2006). Similarly, in our prestudy interviews import managers placed particular emphasis on the extent to which they trusted a foreign partner and were committed to, and satisfied with, an overseas supply relationship to distinguish their favorite business associations. Hence, guided by our field interviews and in harmony with the bulk of relationship quality studies, we view relationship quality as a higher-order construct composed of trust, commitment, and satisfaction.

Trust is probably the most widely studied and accepted construct in relationship marketing (e.g., Geyskens, Steenkamp, \& Kumar, 1998; Madhok, 2006; Morgan \& Hunt, 1994). A frequently used definition of trust is the willingness to rely on an exchange partner in whom one has confidence (Moorman, Zaltman, \& Deshpande, 1992). Trust is critical in buyer-seller relationships that cross-national borders; it lessens the transaction costs of the exchange process as incomplete contracts become sufficient for running the exchange and concurrently augments transaction value via the creation of a positive working environment (e.g., Aulakh, Kotabe, \& Sahay, 1996; Johnson, Cullen, Sakano, \& Takenouchi, 1996; Zhang et al., 2003).

Commitment has also assumed a central role in the development of buyer-seller relationship models (e.g., Anderson \& Weitz, 1992; Cullen, Johnson, \& Sakano, 1995). Commitment is very difficult to emerge without trust in place - the two constructs constitute the cornerstones of relationship marketing (Morgan \& Hunt, 1994). It is defined as the sense of unity binding the importer to its overseas supplier firm (Kim \& Frazier, 1997). It incorporates elements of affiliation, esprit de corps, dedication, and sacrifice (Lin \& Germain, 1999; Lohtia, Bello, Yamada, \& Gilliland, 2005). Thus, committed importers not only put forth maximum efforts toward relationship protection and preservation, but are less inclined to exit the relationship even if a competing supplier occasionally outperforms the existing one (Skarmeas, Katsikeas, \& Schlegelmilch, 2002). It follows that cementing commitment in the cross-national exchange relationship is critical to its longevity (Karanuratna \& Johnson, 1997).

Satisfaction is viewed as an essential part of successful relationships in a number of interfirm studies for over three decades (e.g., Frazier, Gill, \& Kale, 1989; Jap \& Ganesan, 2000; Morgan \& Hunt, 1994). Extant research suggests satisfaction refers to social as well as economic aspects of the exchange (Geyskens, Steenkamp, \& Kumar, 1999). In line with prior research on relationship quality we focus on overall satisfaction (e.g., Dorsch et al., 1998; Ulaga \& Eggert, 2006). It is defined as a positive affective state resulting from the appraisal of all aspects of an importer's working relationship with an exporter (Leonidou \& Kaleka, 1998; Lin \& Germain, 1998). Satisfaction is a focal outcome of buyer-seller relationships that is generally unlikely to develop in the absence of trust and commitment (Cullen et al., 1995; Geyskens et al., 1999).

Our conceptualization points to the role which relationship quality plays in building strong cross-national marketing channel relationships. Importing distributors that are able to develop foreign supplier relationships marked by trust, commitment, and satisfaction can improve the effectiveness and efficiency of the overall purchasing function (e.g., inventory reduction, rapid flow of information, supply availability on an ongoing basis) (Samiee \& Walters, 2006). Notably, the physical and cultural distance almost invariantly present in international distribution channels result in lengthy structures and longer lead times, which call for higher buffer inventories, increase the need for information exchange, and augment the costs of seeking and checking new suppliers (Levy, 1997). It is critical that export managers on the other hand, enhance understanding of key constituent elements of relationship quality (as perceived by their organizational customers) so that they acquire competence in managing international channel partnerships more effectively. This is particularly important, given that poor management of foreign distributor relationships has been identified as a key determinant of poor export performance (Styles \& Ambler, 2000). 


\section{International market characteristics}

Unarguably, the context within which an exchange takes place may affect the nature of the buyer-seller relationship (Achrol, Reve, \& Stern, 1983). Within the international distribution channels literature, the concepts of psychic distance and environmental uncertainty have attracted a great deal of attention (e.g., Bello \& Gilliland, 1997; Klein \& Roth, 1990). The rationale for this lies in that, except for the higher geographic separation between exchange partners, international markets are marked by different social, cultural, political, technical, and economic environments (Terpstra \& Sarathy, 2000). Such differences (e.g., time-zones, language, and legal systems) impinge on exchange partners' management practices and styles, with significant implications for the management of cross-border relationships (Johnston, Lewin, \& Spekman, 1999). Further, as opposed to domestic markets, international operations are characterized by higher levels of environmental uncertainty, due to lack of knowledge and information on overseas markets and the multiplicity of task environments within which the firm must operate (Czinkota \& Ronkainen, 2003). For example, fluctuating exchange rates and problems associated with changing customers' needs and preferences are more pronounced in crossnational marketing channels where trading partners are far from each other. A discussion of how psychic distance and environmental uncertainty may discourage the development of quality in importer-exporter relationships follows.

\subsection{Psychic distance}

In the international business field several models have been proposed to describe the internationalization process of the firm, that is, the way firms grow and develop in overseas markets (Leonidou \& Katsikeas, 1996). A key factor in explaining the internationalization process is the concept of psychic distance, which refers to a set of elements inhibiting the flow of information to and from a particular foreign market (Johanson \& Vahlne, 1977). Drawing from Klein and Roth (1990), psychic distance is defined as the importer's perception of differences between the operating environments of the exchange partners. The lower the degree of dissimilarity, the lower the level of psychic distance surrounding the importer-exporter relationship (Stottinger \& Schlegelmich, 1998).

For relationship quality to develop, a series of buyer-seller relationship building interactions over an extended period of time is needed (Dwyer et al., 1987). But psychic distance has been noted to interrupt the communication flow and social interactions between the exchange parties (Bello \& Gilliland, 1997), which are critical to trust development (Morgan \& Hunt, 1994). For instance, great physical distance renders travel expenses for regular face-to-face meetings and personal visits overwhelming, while language differences make it more difficult to describe and resolve complex technical problems and convey detailed and accurate information. Moreover, because the interacting parties are kept apart and lack a common frame of reference, psychic distance may curtail the desire for the relationship to be important enough to warrant the maximum effort, to the detriment of channel member commitment (Leonidou et al., 2006). In addition, differences in the operating environments of the international exchange partners have been found to increase the potential for misunderstanding between the parties (Shoham, Rose, \& Kropp, 1997), which attenuates satisfaction with the relationship. Hence, in international exchange relations marked by high levels of psychic distance relationship quality levels are likely to suffer.

H1. Importer-exporter relationships surrounded by high levels of psychic distance are expected to be of low quality.

\subsection{Environmental uncertainty}

The issue of environmental uncertainty has its roots in both transaction cost (Williamson, 1985) and power-dependence (Pfeffer \& Salancik, 1978) theories. Moreover, the political economy paradigm (Robicheaux \& Coleman, 1994; Stern \& Reve, 1980) suggests that business relationships are not only a function of conditions internal to the dyad, but also a function of the larger set of environmental forces where sellers and buyers interact. Such forces are particularly relevant in international exchanges, as the two partners belong to different countries (Akhter \& Robles, 2006). Considerable work in the distribution channels literature favors the conclusion that uncertainty is a key environmental dimension that may affect channel relations (e.g., Achrol et al., 1983; Jap \& Ganesan, 2000; Kumar et al., 1995). It is generally associated with unanticipated changes in circumstances surrounding an exchange (Achrol \& Stern, 1988; Rindfleisch \& Heide, 1997). Although various aspects of uncertainty have been proposed in the literature, volatility is the one most frequently studied by channel scholars (e.g., Bello \& Gilliland, 1997; Ganesan, 1994). Volatility refers to the extent to which the environment changes rapidly and allows a firm to be taken by surprise (Klein, Frazier, \& Roth, 1990). In crossnational marketing channels uncertainties such as delays due to inclement whether, labor strikes, and complicated customs clearance procedures are more likely to occur and difficult to predict, which lessens the ability of channel partners to plan effectively for future conditions.

Rapid fluctuations in demand and supply conditions are likely to undermine trust because of the difficulties associated with making accurate predictions. Specifically, trust development entails a prediction process; it requires an assessment of the other party based on a trustor's expectations about the motives and actions of a trustee (Doney \& Cannon, 1997). Under volatile conditions the importing firm may find it difficult to evaluate and anticipate the exporter's behavior. Inability to appraise and predict its counterpart's conduct may cultivate to the importing firm suspicions of exporter untrustworthiness. Further, quickly changing international market conditions can interrupt the routinization necessary for strong relational sentiments to develop (Hofstede, 1991). Thus, uncertainty may hinder the establishment of an importer's sense of unity and rapport with its foreign supplier. Also, prior channel research indicates frequent occurrences of friction, tension, and conflict between partners in uncertain environments (Achrol 
et al., 1983; Klein, 1991; Leonidou et al., 2006). Such incidents promote frustration and dissatisfaction, rather than a positive affective state regarding the overall working relationship. Thus, environmental uncertainty is expected to forestall the development of quality in importer-exporter relationships.

H2. Importer-exporter relationships surrounded by high levels of environmental uncertainty are expected to be of low quality.

\section{Exporter characteristics}

While a variety of exporter characteristics can be linked to the nature of buyer-seller exchanges in an international marketing channel, we posit that an exporter's performance in its channel role and investments specific to the overseas disxtributor play a pivotal role in influencing an importer's perceptions of relationship quality. Role performance and transaction-specific investments lie at the heart of two theoretical perspectives that have dominated the buyer-seller relationship literature, those being power-dependence theory (Pfeffer \& Salancik, 1978) and transaction cost analysis (Williamson, 1985), respectively. A large and growing body of research has relied on role performance and transaction-specific investments to examine interfirm relationship issues (e.g., Anderson \& Weitz, 1992; Frazier et al., 1989; Kim, 2000). Importantly, we focus on what importers think of exporters' role performance and transactionspecific investments, and hence examine drivers that exporting firms may activate in order to improve the quality of their exchange relationship with importing distributors. Below we explain why and how each supplier characteristic is expected to enhance relationship quality.

\subsection{Role performance}

Role performance is defined as how well an exporting firm actually caries out its channel roles in comparison with the industry average (Kim, 2000). It reflects levels of dependence in channel relationships; as the role performance of the source firm increases, the target firm's dependence on the source increases too because the attractiveness of alternative partners available to the target firm decreases (Frazier et al., 1989). In an international channel relationship the importing distributor expects certain behaviors and actions from the exporter, and vice versa. For example, exporting firms expect they can rely on their importing distributors to implement their export marketing programs. On the other hand, an importer needs to know that the exporter will act in a competent fashion. Effective execution of channel roles is vital in cross-border industrial dealings. This is often complicated by the existence of different management styles and practices between the international exchange partners (Poon, Evangelista, \& Albaum, 2005), along with the challenge facing exporters to undertake considerable adaptations to match their product offerings to the particular requirements of foreign customers (Leonidou et al., 2006).

Exporting firms that perform their prescribed roles in an exemplary way (e.g., generation of demand through sales promotion programs, provision of reliable technical assistance) not only enhance their foreign market performance (Katsikeas et al., 2000), but also assist counterparts in attaining their goals (Brown, Lusch, \& Nicholson, 1995). This is likely to cultivate satisfaction in the overseas supply relationship. Moreover, when the importing firm realizes that its foreign partner constitutes a reliable, continuous, and consistent source of supply, it is likely to grant trust to its overseas partner (Johnson et al., 1996; Frazier et al., 1989). Also, an importer that sees that the exporter works hard on its behalf and supports its efforts to market the products is expected to reciprocate and commit to its overseas supply relationship (Cullen et al., 1995; Kim \& Frazier, 1997). Hence, in the presence of superior exporter role performance, enhanced relationship quality is likely to occur.

H3. Importer-exporter relationships characterized by high levels of exporter role performance are expected to be of high quality.

\subsection{Transaction-specific investments}

Transaction-specific investments refer to the assets that are uniquely dedicated to a particular relationship and cannot be easily redeployed in other exchange relationships (Williamson, 1985). Such assets are tailored to the requirements of a specific partner and have considerably less value for the investor outside of the focal relationship (Anderson \& Gatignon, 1986; Rindfleisch \& Heide, 1997). Despite their sunk properties, idiosyncratic investments are common features of many channel relationships (Akhter \& Robles, 2006; Rokkan, Heide, \& Wathne, 2003). For example, exporting firms may often exchange information on new products with importers, develop operating systems for ordering and inventory control, and train the importer's personnel to sale and service their products.

An exporter's investments specific to its overseas distributor are powerful signals that the exporting firm has a vested interest in the maintenance and well-being of the relationship and is willing to share exchange risks and responsibilities with its partner (Jap \& Ganesan, 2000; Skarmeas et al., 2002). This is likely to induce trust by the importer in its counterpart. Moreover, idiosyncratic assets constitute pledges that bind the exporting firm to the exchange relationship - in the event of relationship termination the incumbent firm would not be able to recover its investment (Anderson, \& Gatignon, 1986; Rokkan et al., 2003). Such pledges provide the necessary impetus to the importing firm for committing to its overseas supply relationship. Additionally, due to their task-driven nature, idiosyncratic investments have the ability to create considerable value not only for the incumbent party, but for both exchange partners (Jap \& Ganesan, 2000). Therefore, exporter investments specific to their overseas distributors are likely to enhance importer satisfaction with the overall international exchange relationship. In sum, exporter asset specificity is expected to promote relationship quality.

H4. Importer-exporter relationships characterized by high levels of exporter transaction-specific investments are expected to be of high quality. 


\section{Methodology}

\subsection{Research setting and design}

Importing distributors' relationships with exporting manufacturers provided the research setting for this study. Distributors perform important functions along the value chain, including providing foreign market information, customer contracts, technical support, geographical market coverage, and inventory-holding and order-processing facilities (Rosenbloom \& Larsen, 1992). Given that exporting manufacturers find it difficult to undertake internally such activities, developing high quality relationships with overseas distributors represents a viable and commonly used foreign market entry option (Bello et al., 2003). Hence, this is an appropriate context for the research question investigated here.

Relevant information was collected through a mail survey of key informants in importing firms. Key informants were identified on the basis of being knowledgeable about the phenomena studied as well as being able and willing to provide the information required (Campbell, 1955; Kumar, Stern, \& Anderson, 1993). The key informant technique was used because our field interviews suggested that a single manager was typically responsible for dealing with the overseas supplier; in most cases a second informant did not exist. Extensive telephone screening was used to isolate qualified informants. In addition, key informants were randomly instructed to provide the relevant information with regard to their largest, third largest, or fifth largest foreign supplier. The goal of this approach was to avoid respondent selection bias (i.e., informants uniformly selecting a successful overseas supply relationship) and enhance variation in the responses.

\subsection{Field interviews and questionnaire development}

Multiple items were developed for each construct based on previous studies and extensive exploratory fieldwork. In-depth, on-site interviews, lasting up to $90 \mathrm{~min}$, with ten and three managers in importing and exporting firms, respectively, explored issues related to cross-border relationship quality. Interviewees were encouraged to comment on the relevance and importance of the research issues in the context of importing distributor-exporting manufacturer relationships. The fieldwork provided insights into the nature of cross-national channel relationships. A manager in an importing firm stated emphatically: "We have a very good relationship with them. They are very open and frank and we work closely with them to do what's right for both of us". Another import manager stressed: "Our relationship is neither close nor warm. You have to be cautious in dealing with them. There is little understanding regarding differences in each other's ways of doing business". On the other hand, an export manager said: "What's the point of alienating your client? It's counterproductive". The interviews also complemented the literature review in measure development and ensured that managers could easily understand all study items and constructs.

Then a first draft of the questionnaire was constructed. Academics familiar with research in the areas of interfirm relation- ships and international business judged the extent to which each item was representative of the construct of interest (Zaichkowsky, 1985) and appraised the content validity of the measures selected. Their comments assisted us in eliminating items that were not viewed as 'clearly representative' or 'somewhat representative' of the construct in question, as well as in specifying the conceptual domain of each construct. Next, the revised questionnaire was tested in personal interviews with nine import managers. Their responses helped further refine the research instrument in terms of flow, wording, and length. Finally, a small scale mail pretest was conducted and no particular problems were identified with the interpretability of the measures, instructions, and response formats.

\subsection{Data collection}

The sampling frame consisted of importing distributor firms trading directly with exporting firms. They were identified from the Dun and Bradstreet computerized data bank. Based on a systematic random procedure, a sample of 1000 firms from a cross-section of four industries (i.e., machinery and equipment, chemicals, textile, and paper) was selected. We chose these sectors because they stand for a great volume of U.K. import trade and exhibited a higher propensity toward direct importing than did many others. All importing distributor firms were contacted by telephone to: ensure that the firm was still in business; verify that it was an independent importing distributor trading directly with foreign manufacturers as well as its contact details; and identify the key informant for the study, explain the purpose of the project, and request his/her participation. On the basis of multiple telephone calls, key informants in 606 firms that consented to take part in the study were identified. Specifically, 394 firms were dropped for various reasons (e.g., corporate policy of no participation, importing via a trading company, incorrect contact details).

The guidelines specified by the Total Design Method (Dillman, 1978) were employed in administering the mail survey. Except for the telephone calls, a personalized letter was mailed to the identified key informant of the 606 sample firms describing the nature and importance of the study and prenotifying the dispatch of the questionnaire. One week later, a cover letter, accompanied by the questionnaire and a postagepaid return envelope were sent to the same individual. Confidentially was assured and all participants were offered an executive summary of the findings upon completion of the study. Reminder 'thank you' postcards, followed by two further waves of questionnaires and telephone approaches to all nonrespondents, generated a total of 317 responses. Nevertheless, 25 questionnaires were inadequately completed and thus eliminated. Thus, a total of 292 eligible responses were received, constituting an effective response rate of $48 \%$. Of these, 177 importing firms were involved in the distribution of industrial products, which provided the focus of this study.

\subsection{Sample profile}

Our sampling method succeeded in collecting data that varied considerably on both relationship and respondent characteristics. 
The sample firms varied in size, measured in terms of employee number $(\leq 10,27.7 \% ; 11-25,16.4 \% ; 26-50,16.9 \% ; 51-100$, $15.8 \%$; and $\geq 100,23.2 \%)$, import-to-total purchase ratio $(\leq 10$, $5.9 \% ; 11-20,5.8 \% ; 21-30,6.5 \% ; 31-40,10.2 \%, 41-50,8.2 \%$; $51-60,6.7 \% ; 61-70,8.3 \% ; 71-80,12.1 \% ; 81-90 \%, 16.8 \%$; and $\geq 90,19.5 \%)$, and years of importing experience $(\leq 10,13.6 \%$; $11-20,29.3 \%$; 21-30, 32.2\%; 31-50, 16.4\%; and $\geq 51,8.5 \%$ ). Respondents had been involved with the identified supplier for an average of 6.7 years and commonly held senior management positions including purchasing and import managers (44.1\%), directors $(33.8 \%)$, and sales and business development managers $(14.5 \%)$. Finally, the industry distribution in our sample was machinery and equipment $28.7 \%$, chemicals $24.4 \%$, textile $27.1 \%$, and paper $19.8 \%$.

\subsection{Construct operationalization}

\subsubsection{Psychic distance}

A five-item scale was used, describing the perceived dissimilarity between foreign and domestic operating environments in terms of culture (traditions, values, and language), accepted business practices, economic environment, legal system, and communications infrastructure. Psychic distance items were adapted from Klein and Roth (1990) and anchored by very similar (1) and very different (7). National differences regarding the institutional, economic, and managerial contexts within which cross-border exchange partners are located and variance of cultural distance between markets pose additional challenges to international management, compared with business relationships in the domestic market (Levy, 1997).

\subsubsection{Environmental uncertainty}

Four items were used to measure the degree to which the environment surrounding the exchange changes rapidly, adapted from Klein et al. (1990) and Ganesan (1994). A seven-point semantic differential scale was utilized to capture participant responses for each item (stable/volatile market shares, easy/ difficult to monitor trends, stable/volatile industry volume, accurate/inaccurate sales forecasts). Monitoring market conditions and anticipating market changes is an inherently difficult, but necessary, managerial task. In international marketing channels, the physical separation and distance between the upstream and downstream markets, coupled with the associated information asymmetry, further complicates this task. It becomes more difficult for international exchange partners to know each other well and be aware of any movements in the buying or selling markets (Samiee \& Walters, 2003). This renders the construct of environmental uncertainty particularly important in gauging the dynamics and nature of relationships formed across national boundaries.

\subsubsection{Role performance}

Importers' perceptions of exporters' role performance were assessed drawing from Kim's (2000) operationalization. Eight basic elements of the supplier's role in an international distribution channel were identified and itemized on the basis of field interviews and pretests. These elements are product quality, pricing policy, sales and product training, product and parts availability, sales promotion programs and promotional aids, technical assistance, order processing and delivery, and return goods policy. Respondents assessed exporter performance in the identified areas on a 7-point scale, with 1 indicating very poor and 7 indicating very good.

\subsubsection{Transaction-specific investments}

Four items were used to measure exporters' investments specific to their overseas distributors (this foreign supplier has invested a great deal in our business, gone out of its way to link us with their product line, made substantial investments in training our people, invested substantially in personnel dedicated to our business). They were drawn from Anderson and Weitz (1992). Respondents indicated their level of agreement on a 7-point Likert scale, with strongly disagree (1) and strongly agree (7) as the anchors.

\subsubsection{Trust}

Four items were employed to capture an importer's trust in the exporter adapted from Ganesan (1994). The items assessed the extent to which the focal foreign supplier is honest about problems that might arise (i.e., shipment delay), is not making false claims, is reliable on keeping its promises, and has been on the importer's side. Informants answered on a 7-point Likert scale, with 1 indicating strongly disagree and 7 indicating strongly agree.

\subsubsection{Commitment}

A four-item scale, reflecting importers' sense of commitment to their overseas supplier relationships (this supplier is a very important ally of our distributorship, we lack a strong business link with the supplier (reversed), a high sense of unity exists between this supplier and us, we have developed a close business relationship with this supplier). The items were drawn from Kim and Frazier (1997). We used a 7-point Likert scale, ranging from strongly disagree (1) to strongly agree (7), to capture participant responses.

\subsubsection{Satisfaction}

Five items were used to tap the extent to which the importing firm was satisfied with its working relationship with the overseas supplier (in general, we are satisfied with our dealings with this supplier, we would discontinue selling this supplier's product if we could (reversed), this supplier is a good company to do business with, if we had to do it over again, we would not do business with this supplier (reversed), on the whole, we are satisfied with the products and services we get from this supplier). The items were borrowed from Frazier et al. (1989) and Anderson and Narus (1990). The respondents answered on a 7-point Likert scale, with 1 indicating strongly disagree and 7 indicating strongly agree.

\subsection{Control variables}

We control for possible sources of systematic bias using three variables: Importer size, defined as the number of full-time employees; relationship length, reflected in the number of years the importer and the exporter have been doing business with 
Table 1

Measurement models

\begin{tabular}{|c|c|c|c|c|c|}
\hline \multicolumn{3}{|c|}{ Measurement model 1} & \multicolumn{3}{|c|}{ Measurement model 2} \\
\hline \multicolumn{3}{|c|}{$\begin{array}{l}\text { First-order construct measurement summary: confirmatory } \\
\text { factor analysis }\end{array}$} & \multicolumn{3}{|c|}{$\begin{array}{l}\text { Relationship quality measurement summary: second-order confirmatory } \\
\text { factor analysis }\end{array}$} \\
\hline Factors and items & Standardized loading & $t$-value & Factors and items & Standardized loading & $t$-value \\
\hline \multicolumn{3}{|l|}{ Psychic distance } & \multicolumn{3}{|l|}{ First-order factors } \\
\hline Pd1 & .73 & 10.24 & Trust & & - \\
\hline $\operatorname{Pd} 2$ & .75 & 10.52 & $\operatorname{Tr} 1^{\mathrm{a}}$ & .84 & - \\
\hline $\mathrm{Pd} 3$ & .72 & 10.06 & $\operatorname{Tr} 2$ & .81 & 12.39 \\
\hline $\mathrm{Pd} 4$ & .72 & 9.93 & $\operatorname{Tr} 3$ & .86 & 13.70 \\
\hline $\operatorname{Pd} 5$ & .70 & 9.62 & \multicolumn{2}{|l|}{ Commitment } & 14.81 \\
\hline \multicolumn{3}{|c|}{ Environmental uncertainty } & Com $1^{\mathrm{a}}$ & .83 & - \\
\hline Eu1 & .69 & 9.30 & Com2 & .75 & 10.43 \\
\hline $\mathrm{Eu} 2$ & .73 & 9.99 & Com3 & .80 & 11.32 \\
\hline Eu3 & .81 & 11.35 & Com4 & .85 & 12.19 \\
\hline Eu4 & .80 & 9.44 & \multicolumn{3}{|l|}{ Satisfaction } \\
\hline \multicolumn{3}{|l|}{ Role performance } & Sat2 & .82 & 13.74 \\
\hline Rp1 & .96 & 16.77 & $\begin{array}{l}\text { Sat3 } \\
\text { Sat4 }\end{array}$ & $\begin{array}{r}.88 \\
.81\end{array}$ & $\begin{array}{l}15.70 \\
13.25\end{array}$ \\
\hline \multicolumn{3}{|c|}{ Transaction-specific investments } & Sat5 & .86 & 14.90 \\
\hline Tsi1 & .73 & 10.14 & \multicolumn{3}{|l|}{ Srcond-order factor } \\
\hline Tsi2 & .64 & 8.64 & \multicolumn{3}{|l|}{ Relationship quality } \\
\hline Tsi3 & .78 & 11.21 & Trust & .75 & 7.52 \\
\hline \multirow[t]{2}{*}{ Tsi4 } & .85 & 12.44 & Commitment & .65 & 6.71 \\
\hline & & & Satisfaction & .74 & 7.69 \\
\hline
\end{tabular}

Diagnostics for measurement model $1: \chi_{(72)}^{2}=86.74, p=.114, \mathrm{CFI}=.99, \mathrm{NNFI}=.98, \mathrm{IFI}=.99, \mathrm{RMSEA}=.04, \mathrm{AOSR}=.04$.

Diagnostics for measurement model 2: $\chi_{(62)}^{2}=121.77, p<.001, \mathrm{CFI}=.98, \mathrm{NNFI}=.97, \mathrm{IFI}=.98, \mathrm{RMSEA}=.07, \mathrm{AOSR}=.04$.

a Item fixed to set the scale.

each other; and import intensity, reflected in the percentage of distributor purchases accounted for by import purchases. Presumably, large firms will allocate greater resources to dealing with the overseas supply relationship, to the benefit of relationship quality. Prior research in the realms of international marketing has shown that larger companies tend to perform better, as operating in overseas markets requires substantial commitment of resources (e.g., Christensen, Rocha, \& Gertner, 1987). Further, it is possible as relationship age and the ratio of total-to-import purchases increases, the quality of the importer-exporter working relationship rises by virtue of enhanced importer experience. Accumulation of experiential knowledge from actual business operations abroad with a specific exporting firm is particularly important in international relationship marketing where relationship building activities (e.g., social visits, day-to-day communication) are more expensive and less convenient compared with domestic business relationships (Samiee \& Walters, 2003).

\subsection{Nonresponse}

The issue of nonresponsse bias was addressed in two independent tests. First, certain characteristics of early respondents, namely employee number, sales volume, import purchase volume, years of importing, and number of overseas supply markets were compared to those of late respondents. Second, demographic characteristics (number of employees, years of importing, and sales volume) of 84 randomly selected non- respondents were compared to those of all respondents. In both cases, no statistically significant differences were observed at the conventional level of .05, suggesting that nonresponse bias is not likely to be a problem in this research.

\section{Data analysis}

\subsection{Measure validation}

Following Gerbing and Hamilton's (1996) protocol for measure validation and purification, we first examined the reflective scales using exploratory factor and reliability analyses and then using confirmatory factor analysis. Exploratory factor analysis revealed low cross-loadings and strong individual loadings on each factor. Internal consistency analysis indicated that, with the exception of role performance, the Cronbach's alpha scores of the study constructs ranged from .82 to .93. Role performance was treated as a formative scale. The rationale for this lies in that each role performance item embodies a single dimension of the role performance construct (Frazier et al., 1989). To assess the validity of such multidimensional composites, examination of the construct domain as well as the way the construct relates to other variables is necessary (Diamantopoulos \& Winklhofer, 2001; Howell, 1992). Prior research on distribution channels provides ample evidence on the theoretical grounding of the measure (e.g., Frazier et al., 1989; Kim, 2000). Further, confirmation of the research hypotheses would add credence to the validity of the role performance measure 
employed (Bollen \& Lennox, 1991). Thus, individual performance ratings were aggregated to construct an index of supplier role performance.

Measure validation begun with two confirmatory factor analyses (Bollen \& Lennox, 1991) estimated using EQS (Bentler, 1995). One measurement model was estimated for the four firstorder constructs of psychic distance, environmental uncertainty, role performance, and transaction-specific investments. The results shown in Table 1 suggest the model fit is very good, with a $\chi^{2}$ of $86.74(d f=72)$, a CFI of .99, a NNFI of .98, an IFI of .99, a RMSEA of .04, and an AOSR of .04. All standardized loadings are significant and of large magnitude (the lowest $t$-value is 8.64), which provides evidence of convergent validity. Also, pair-wise comparisons of the constructs showed that the confidence interval (plus/minus two standard errors) around the correlation estimate for each pair of constructs never included 1.00, which indicates discriminant validity (Gerbing \& Anderson, 1988).

Another measurement model was run for the construct of relationship quality, which is posited to have a second-order factor structure with trust, commitment, and satisfaction as its first-order factors (e.g., Bruggen et al., 2005; Kumar et al., 1995). The results of this model presented in Table 1 indicate that trust, commitment, and satisfaction can be modelled with our data as being reflected by the higher-order construct of relationship quality. Favorable diagnostics of the model include a CFI of .98, a NNFI of .97, an IFI of .98, a RMSEA of .07, and an AOSR of .04. Only the $\chi^{2}$ is statistically significant $\left(\chi_{(62)}^{2}=\right.$ $121.77, p<.001)$, but this is expected due to this test statistic's sensitivity to smaller sample sizes (Gerbing \& Anderson, 1988). Moreover, the first- and second-order loadings are all large and significant. Having established the validity of our relationship quality measure, composite scores were used to reflect the underlying construct dimensions. Table 2 displays the zeroorder correlations of the study constructs. A complete list of the construct measures, mean values, standard deviations, and alpha scores is presented in the Appendix A.

\subsection{Results}

The research hypotheses were tested using structural equation modelling (Bentler, 1995). The results (Table 3) indicate that the overall fit of the model is $\operatorname{good}\left(\chi_{(167)}^{2}=206.59, p=.020\right.$, $\mathrm{CFI}=.97, \mathrm{NNFI}=.97, \mathrm{IFI}=.97 \mathrm{RMSEA}=.04$, and $\mathrm{AOSR}=.05)$. Both hypotheses regarding exporter characteristics are supported, while one out of the two hypotheses concerning environmental characteristics is confirmed. Specifically, in support

Table 2

Correlation matrix

\begin{tabular}{lccrrrr}
\hline Measures & & $\mathrm{X} 1$ & $\mathrm{X} 2$ & $\mathrm{X} 3$ & $\mathrm{X} 4$ & $\mathrm{X} 5$ \\
\hline Psychic distance & $\mathrm{X} 1$ & 1.00 & & & & \\
Environmental uncertainty & $\mathrm{X} 2$ & -.01 & 1.00 & & & \\
Role performance & $\mathrm{X} 3$ & -.03 & -.08 & 1.00 & & \\
Transaction-specific investments & $\mathrm{X} 4$ & .04 & .04 & .09 & 1.00 & \\
Relationship quality & $\mathrm{X} 5$ & $-.20 *$ & -.01 & $.25^{*}$ & $.22 *$ & 1.00 \\
\hline$* p<.01$. & & & & & &
\end{tabular}

Table 3

Structural equation model results

\begin{tabular}{llc}
\hline Hypotheses & Standardized estimate & $t$-value \\
\hline Psychic distance $\rightarrow$ Relationship quality & -.24 & $-2.55^{*}$ \\
$\quad$ Environmental uncertainty $\rightarrow$ Relationship & -.02 & -.23 \\
$\quad$ quality & & \\
Role performance $\rightarrow$ Relationship quality & .28 & $3.15^{* *}$ \\
$\quad$ Transaction-specific & .20 & $2.20^{*}$ \\
$\quad$ investments $\rightarrow$ Relationship quality & & \\
& & \\
Control variables & -.05 & -.05 \\
Size $\rightarrow$ Relationship quality & .21 & $2.35^{*}$ \\
Relationship length $\rightarrow$ Relationship quality & .18 & $2.13^{*}$ \\
Import intensity $\rightarrow$ Relationship quality & .18
\end{tabular}

Model diagnostics: $\chi_{(167)}^{2}=206.59, p=.020, \mathrm{CFI}=.97, \mathrm{NNFI}=.97, \mathrm{IFI}=.97$, RMSEA $=.04, \mathrm{AOSR}=.05$

$* p<.05$.
$* * \quad p<.01$.

of $\mathrm{H} 1$, psychic distance is related negatively to relationship quality $(\beta=-.24, t=-2.55)$. Contrary to expectations, no significant connection is found between environmental uncertainty and relationship quality $(\beta=-.02, t=-.23)$, indicating lack of support for H2. In line with $\mathrm{H} 3$, exporter role performance is associated positively with the quality of the importer-exporter relationship $(\beta=.28, t=3.15)$. As predicted in $\mathrm{H} 4$, exporters' investments specific to their overseas distributors' trading associations are related positively to relationship quality $(\beta=.20$, $t=2.20)$. Also, relationship length $(\beta=.21, t=2.35)$ and import intensity $(\beta=.18, t=2.13)$ were shown to play a positive role in the development of relationship quality. Further, the results of our model show that the study constructs collectively explain over a quarter $(26 \%)$ of the observed variance in the endogenous construct of relationship quality.

\subsection{Alternative model}

Our structural model suggests that certain market and exporter characteristics affect relationship quality which is viewed as a higher-order construct composed of trust, commitment, and satisfaction. A rival model might posit that trust, commitment, and satisfaction constitute distinct dependent variables, rather than being dimensions of a second-order construct. This possibility was considered in a rival structural model which yielded $\chi_{(389)}^{2}=800.95, p<.001, \mathrm{CFI}=.91, \mathrm{NNFI}=.90, \mathrm{IFI}=.91$, $\mathrm{RMSEA}=.06$, and $\mathrm{AOSR}=.08$. These goodness-of-fit results are considerably worse than the corresponding indices in our structural model. Therefore, it might be concluded that the rival model is not only less parsimonious, but also does not explain the data as well as the proposed structural model.

\section{Discussion}

Despite the repeated pleas for more systematic research on the nature of cross-national business relationships (Leonidou, 2003; Sheth \& Parvatiyar, 2001), relationship marketing studies in an international context have lagged behind those in domestic settings (Samiee \& Walters, 2003). This is a critical gap in the 
literature given the increasing trend toward globalization, along with the additional ramifications of relationship marketing in business relations that transcend national boundaries (Samiee \& Walters, 2006). In addressing this research void, the present study investigates the degree to which certain environmental and exporter characteristics influence the quality of buyerseller relationships from the importer's perspective. This viewpoint is important partly due to the limited research on importers' behavior (Liang \& Parkhe, 1997; Quintens et al., 2006), but mainly due to the fact that importing distributors are the business customers of exporting manufacturers and, therefore, the final decision-makers (Cannon \& Perreault, 1999). Identification of foreign market and exporter characteristics that play an important role in determining the quality of cross-national exchange relationships may offer international business practitioners valuable insights into successful relationship management and serve as a stimulant to further research in this important, but understudied, area. A discussion of the study findings follows.

The international marketing literature cites psychic distance as a critical problem to the firm's progression along the internationalization path (e.g., Johanson \& Vahlne, 1990; Leonidou \& Katsikeas, 1996; Shoham \& Albaum, 1995). Adding to the extant knowledge base, this study identifies psychic distance as a significant impediment to the development of quality in the relationships between importing distributors and exporting manufactures. This finding suggests that, despite the increased homogeneity of world markets and interaction among crossnational channel partners due to the tremendous growth in global channels transactions (Stottinger \& Schlegelmilch, 2000), psychic distance remains a key parameter in international marketing research that still sets part of the agenda for doing business abroad. Developing relationship quality between channel partners in a domestic context where parties are geographically closer and have a similar background is not an easy task (Dwyer et al., 1987). When the business relationship transcends national borders, where geographical gaps widen and trading parties come from different cultural backgrounds (Sousa \& Bradley, 2006), the challenge can be even greater. In an attempt to bridge psychic distance differences, international channel partners should invest time, effort, and resources in gathering information and accumulating knowledge about their exchange counterpart's operating environment (i.e., culture, traditions, business values and practices). A move in these directions can provide a solid basis for mitigating the detrimental role of psychic distance in the development of quality importer-exporter relationships.

No link was established in this study between the extent to which rapid changes take place in the market environment surrounding the exchange and the level of quality of importerexporter relationships - environmental uncertainty was not found to inhibit relationship quality. One possible explanation lies in that turbulent environmental conditions may not necessarily forestall the development of high quality business relationships. Specifically, while we hypothesized that environmental uncertainty results in looser relationship ties, one may also argue the opposite: in the face of volatile market conditions exchange partners need to cultivate closer business relationships, which inherently allow for flexible adaptation to changing circumstances (Rindfleisch \& Heide, 1997). Further, perhaps other types of environmental uncertainty such as diversity, concentration, and capacity (cf. Achrol \& Stern, 1988) play a more prominent role in affecting quality in cross-border channel relationships. For example, because international channel partners are located in different countries, it is possible that difficulties in collecting, interpreting, and assimilating relevant market information stem from the multiplicity, rather than dynamism, of task environments within which each firm operates (Czinkota \& Ronkainen, 2003). However, before clear conclusions can be reached here, more research is required to examine the effects of different facets of environmental uncertainty on relationship quality.

The study findings also indicate that exporter role performance has the strongest bearing on importers' perceptions of quality in their overseas supply relationships. This is in harmony with prior research evidence suggesting that suppliers can boost the quality of their relationships with organizational customers by performing their expected functions effectively (Bruggen et al., 2005; Walter et al., 2003). Elements of exporter role performance that promote relationship quality include product quality, pricing policy, sales training and promotion programs, product and parts availability, technical assistance, order processing and delivery, and return goods policy. Fulfillment of such functions constitutes inputs into the overall system and operations of the importer, with beneficial implications for relationship quality. International managers should pay particular attention to the positive impact of role performance on relationship quality, since unilateral forms of governance such as administrative control and contractual agreements are not always practical alternatives in cross-border relationships (Bello \& Zhu, 2006; Zhang et al., 2003). It is important to note that while relationship quality is measured from the importer's standpoint, role performance is actually controlled by the exporter. Hence, deliberate engendering of the importer's perception of relationship quality by the exporter is possible through the effective demonstration of international channel functions fulfillment.

The results of the study also reveal that an exporter's investments idiosyncratic to an importing distributor tend to enhance an importer's perception of relationship quality. From a governance perspective (Rindfleisch \& Heide, 1997), this finding indicates that transaction-specific investments may move cross-border channel relationships away from arms-length arrangements toward close, relational partnerships (Bello et al., 2003; Samiee \& Walters, 2006). Although such nonfungible assets incur the risks of expropriation and should be allocated with caution, their deployment seems necessary in that they act as a springboard to the elevation of developing relationship quality. Managers in exporting firms, therefore, should not only invest in idiosyncratic assets, but also make such nonrecoverable investments visible to managers in importing firms. They should make every endeavor to communicate and display the existence of their relationship-specific assets. This is particularly important in an international context given that their importing 
distributors are located in a distant country or region. Decisionmakers in importing firms, in turn, should place emphasis on identifying exporting firms that have the willingness and ability to invest in relationship-specific assets and hence the potential to develop a high quality cross-border relationship. Further, given the growing tendency toward supplier stratification in industrial markets, asset specificity can be used as a criterion for selecting, monitoring, and determining partner status. It appears that exporting firms that dedicate investments to their overseas distributor relationships may succeed in the arduous task of developing relationship quality.

\section{Limitations and suggestions for future research}

Like all studies, our results and implications should be viewed in the context of certain shortcomings that need to be considered. The first limitation of this research is that it focuses only on importing distributor-exporting manufacturer relationships. Caution should be exercised in generalizing the study findings to other settings. Supplier-manufacturer or franchiserfranchisee relationships can presumably yield different pattern of results. The study needs to be expanded to different types of interfirm exchange in an international context to examine whether construct relations hold and make meaningful interpretations. Similarly, given that exporter-overseas distributor relationships are part of a supply chain system (Samiee \& Walters, 2006), a valuable contribution would be to study whether and how other relationships in the larger network affect the development of relationship quality.

Moreover, the cross-sectional design used limits our ability to make for causal inferences. This is only possible with longitudinal studies. For example, the temporal order between transaction-specific investments and relationship quality is not obvious as they both may be seen as prerequisites for, as well as effects of each other. Additionally, it is possible that the antecedents as well as the components of relationship quality vary at different relationship stages (e.g., exploration, growth, and maturity phases). Hence, an important direction for future research concerns embarking on longitudinal research. Monitoring a standard set of international channel relationships at regular intervals may track variations in relationship quality and explain its connectedness with antecedent factors in a more thorough fashion. The challenges involved in this type of investigations notwithstanding, the hurdles to conducting longitudinal research do not seem insurmountable.

Also, data were collected from one part of the dyad: the importers. The possibility that the exporter's perspective offers a different picture of the relationship is present. Dyadic data should be collected and used to provide a holistic view of importer-exporter relationships. Despite the logistical barriers to collecting paired data inherent in international marketing channels research, such an approach would contribute greatly to theory development and the advancement of management practice in the field. Communication and collaboration among international marketing scholars seems a relatively convenient and inexpensive way to undertaking dyadic studies in a crossborder setting and is therefore strongly encouraged.
In addition, prior research has shown that the development of relationship quality can be influenced by different sets of predictors such as interpersonal characteristics (i.e., similarity in terms of life stage, culture, and work attitudes) (Smith, 1998) and relationship structure (i.e., interdependence) (Kumar et al., 1995). Different bundles of relationship quality antecedents such as relationship governance modes (e.g., relational norms), product characteristics (e.g., product complexity), and Hofstede's (1991) cultural dimensions (e.g., collectivism/individualism) should be explored. Likewise, researchers could also investigate whether and how the nature of buyer-seller relationships changes when exchange takes place via private networks or/and the Internet. Further, while there is a substantial amount of effort in channels research devoted to understanding relationship quality, its effects on performance have been relatively ignored. From a managerial perspective, it is far more interesting to assess the performance implications of relationship quality in international marketing channels rather than relationship quality in and of itself. Research along these lines is sorely needed.

\section{Appendix A}

Constructs, scale items, descriptive statistics, and reliability estimates

Psychic distance $($ mean $=4.33$, standard deviation $=1.19, \alpha=.84)$

Culture (traditions, values, language)

Accepted business practices

Economic environment

Legal system

Communication infrastructure

Environmental uncertainty $($ mean $=4.34$, standard deviation $=1.12, \alpha=.82$ )

Stable/volatile market shares

Easy/difficult to monitor trends

Stable/volatile industry volume

Accurate/inaccurate sales forecasts

Role performance $(\text { mean }=4.67 \text {, standard deviation }=1.14)^{\mathrm{a}}$

Product quality

Pricing policy

Sales and product training

Product and parts availability

Sales promotion programs and promotional aids

Technical assistance

Order processing and delivery

Return goods policy

Transaction-specific investments $($ mean $=4.10$, standard deviation $=1.50, \alpha=.84$ ) This foreign supplier has invested a great deal in our business

This foreign supplier has gone out of its way to link us with their product line This foreign supplier has made substantial investments in training our people This foreign supplier has invested substantially in personnel dedicated to our business

Relationship quality

Trust $($ mean $=4.45$, standard deviation $=1.40, \alpha=.92)$

Supplier's honesty about problems that might arise (i.e., shipment delay)

Feeling that the supplier has been on our side

Supplier's not making false claims

Supplier's reliability of promises

Commitment $($ mean $=4.66$, standard deviation $=1.24, \alpha=.88)$

Supplier being a very important ally of our distributorship

Lacking a strong business link with the supplier $(R)$

Existence of a high sense of unity exists between this supplier and us

Development of a close business relationship with this supplier

Satisfaction $($ mean $=4.49$, standard deviation $=1.12, \alpha=.93)$

In general, we are satisfied with our dealings with this supplier 
Appendix A (continued)

Relationship quality

We would discontinue selling this supplier's product if we could $(R)$

This supplier is a good company to do business with

If we had to do it over again, we would not do business with this supplier $(R)$

On the whole, we are satisfied with the products and services we get from this supplier

${ }^{\mathrm{a}}$ Formative scale.

\section{References}

Achrol, R. S., Reve, T., \& Stern, L. W. (1983). The environment of marketing channel dyads: A framework for comparative analysis. Journal of Marketing, 47(4), 55-67.

Achrol, R. S., \& Stern, L. W. (1988). Environmental determinants of decisionmaking uncertainty in marketing channels. Journal of Marketing Research, 25(1), 36-50.

Akhter, S. H., \& Robles, F. (2006). Leveraging internal competency and managing environmental uncertainty: Propensity to collaborate in international markets. International Marketing Review, 23(1), 98-115.

Anderson, E., \& Gatignon, H. (1986). Modes of foreign entry: A transaction cost analysis and propositions. Journal of International Business Studies, 17(3), $1-26$.

Anderson, J., Hakansson, H., \& Johanson, J. (1994). Dyadic business relationships within a business network context. Journal of Marketing, 58(4), 1-15.

Anderson, J. C., \& Narus, J. A. (1990). A model of distributor firm and manufacturer firm working partnerships. Journal of Marketing, 54(1), 42-58.

Anderson, J. C., \& Narus, J. A. (1991). Partnering as a focused market strategy. California Management Review, 33(2), 95-113.

Anderson, E., \& Weitz, B. A. (1992). The use of pledges to build and sustain commitment in distribution channels. Journal of Marketing Research, 24(1), 18-34.

Aulakh, P. S., Kotabe, M., \& Sahay, A. (1996). Trust and performance in crossborder marketing relationships: A behavioral approach. Journal of International Business Studies, 27(5), 105-113.

Barkema, H. G., \& Vermeulen, F. (1997). What differences in the cultural backgrounds of partners are detrimental for international joint ventures? Journal of International Business Studies, 28(4), 845-864.

Bello, D. C., Chelariu, C., \& Zhang, L. (2003). The antecedents and performance consequences of relationalism in export distribution channels. Journal of Business Research, 56(1), 1-16.

Bello, D. C., \& Gilliland, D. I. (1997). The effects of output controls, process controls, and flexibility on export channel performance. Journal of Marketing, 61(1), 22-38.

Bello, B. C., \& Zhu, M. (2006). Global marketing and procurement of industrial products: Institutional design of interfirm functional tasks. Industrial Marketing Management, 35(5), 545-555.

Bentler, P. M. (1995). Structural equations program manual. Los Angeles: BMDP Statistical Software.

Bollen, K., \& Lennox, R. (1991). Conventional wisdom on measurement: A structural equation perspective. Psychological Bulletin, 110(2), 305-314.

Bove, L. L., \& Johnson, L. W. (2001). Customer relationships with service personnel: Do we measure closeness, quality or strength? Journal of Business Research, 54(3), 189-197.

Brown, J. R., Lusch, R. F., \& Nicholson, C. Y. (1995). Power and relationship commitment: Their impact on marketing channel performance. Journal of Retailing, 71(4), 363-392.

Bruggen, V. G. H., Kacker, M., \& Nieuwlaat, C. (2005). The impact of channel function performance on buyer-seller relationships in marketing channels. International Journal of Research in Marketing, 22(2), 141-158.

Campbell, D. T. (1955). The informant in quantitative research. American Journal of Sociology, 60(1), 339-342.

Cannon, J. P., \& Perreault, W. D., Jr. (1999). Buyer-supplier relationships in business markets. Journal of Marketing Research, 36(4), 439-460.

Cavusgil, S. T. (1998). International partnering-A systematic framework for collaborating with foreign business partners. Journal of International Marketing, 6(1), 91-107.
Cavusgil, S. T., Deligonul, S., \& Zhang, C. (2004). Curbing foreign distributor opportunism: An examination of trust, contracts, and the legal environment in international channel relationships. Journal of International Marketing, 12(2), 7-27.

Christensen, C. H., Rocha, A., \& Gertner, R. K. (1987). An empirical investigation of factors influencing exporting success of Brazilian firms. Journal of International Business Studies, 18(3), 61-77.

Crosby, L. A., Evans, K. R., \& Cowles, D. (1990). Relationship quality in services selling: An interpersonal influence perspective. Journal of Marketing, 54(3), 68-81.

Cullen, J. B., Johnson, J. L., \& Sakano, T. (1995). Japanese and local partner commitment to IJVs: Psychological consequences of outcomes and investments in the IJV relationship. Journal of International Business Studies, 26(1), 91-115.

Czinkota, M. R., \& Ronkainen, I. A. (2003). International marketing. Cincinnati: Thomson Press.

Diamantopoulos, A., \& Winklhofer, H. M. (2001). Index construction with formative indicators: An alternative to scale development. Journal of Marketing Research, 38(2), 269-277.

Dillman, D. (1978). Mail and telephone surveys: The total design method. New York: John Wiley and Sons.

Doney, P. M., \& Cannon, J. P. (1997). An examination of the nature of trust in buyer-seller relationships. Journal of Marketing, 61(2), 35-51.

Dorsch, M. J., Swanson, S. R., \& Kelley, S. W. (1998). The role of relationship quality in the stratification of vendors as perceived by customers. Journal of the Academy of Marketing Science, 26(2), 128-142.

Dwyer, F. R., Schurr, P. H., \& Oh, S. (1987). Developing buyer-seller relationships. Journal of Marketing, 51(3), 11-27.

Erramilli, M. K. (1996). Nationality and subsidiary ownership patterns in multinational corporations. Journal of International Business Studies, 27(2), $225-248$.

Farrelly, F. J., \& Quester, P. G. (2005). Examining important relationship quality constructs of the focal sponsorship exchange. Industrial Marketing Management, 34(3), 311-319.

Frazier, G. L., Gill, J. D., \& Kale, H. (1989). Dealer dependence levels and reciprocal actions in a channel of distribution in a developing country. Journal of Marketing, 53(1), 50-69.

Ganesan, S. (1994). Determinants of long-term orientation in buyer-seller relationships. Journal of Marketing, 58(2), 1-19.

Gerbing, D. W., \& Anderson, J. C. (1988). An updated paradigm for scale development incorporating unidimensionality and its assessment. Journal of Marketing Research, 25(2), 186-192.

Gerbing, D. W., \& Hamilton, J. G. (1996). Viability of exploratory factor analysis as a precursor to confirmatory factor analysis. Structural Equation Modeling, 3(1), 62-72.

Geyskens, I., Steenkamp, J. -B. E. M., \& Kumar, N. (1998). Generalizations about trust in marketing channel relationships using meta-analysis. International Journal of Research in Marketing, 15(3), 223-248.

Geyskens, I., Steenkamp, J. -B. E. M., \& Kumar, N. (1999). A meta-analysis of satisfaction in marketing channel relationships. Journal of Marketing Research, 36(2), 223-238.

Ha, J., Karande, K., \& Singhapakdi, A. (2004). Importers' relationships with exporters: Does culture matter? International Marketing Review, 21(4/5), 447-461.

Han, S. -L., Wilson, D. T., \& Dant, S. P. (1993). Buyer-supplier relationships today. Industrial Marketing Management, 22(4), 331-338.

Henning-Thurau, T., Gwinner, K. P., \& Gremler, D. D. (2002). Understanding relationship marketing outcomes: An integration of relational benefits and relationship quality. Journal of Service Research, 4(3), 230-247.

Hewett, K., Money, R. B., \& Sharma, S. (2002). An exploration of the moderating role of buyer corporate culture in industrial buyer-seller relationships. Journal of the Academy of Marketing Science, 30(3), 229-239.

Hibbard, J. D., Kumar, N., \& Stern, L. W. (2001). Examining the impact of destructive acts in marketing channel relationships. Journal of Marketing Research, 38(1), 45-61.

Hofstede, G. (1991). Cultures and organizations: Software of the mind. London: McGraw-Hill. 
Howell, D. C. (1992). Statistical methods for psychology. Belmont: Duxbury Press.

Jap, S. D., \& Ganesan, S. (2000). Control mechanisms and the relationship life cycle: Implications for safeguarding specific investments and developing commitment. Journal of Marketing Research, 37(2), 227-245.

Jap, S. D., Manolis, C., \& Weitz, B. A. (1999). Relationship quality and buyerseller interactions in channels of distribution. Journal of Business Research, 46(3), 303-313.

Johanson, J., \& Vahlne, J. E. (1977). The internationalization process of the firm: A model of knowledge development and increasing foreign market commitments. Journal of International Business Studies, 8(3/4), $23-32$.

Johanson, J., \& Vahlne, J. E. (1990). The mechanism of internationalization. International Marketing Review, 7(4), 11-24.

Johnson, J. L., Cullen, J. B., Sakano, T., \& Takenouchi, H. (1996). Setting the stage for trust and strategic integration in Japanese-U.S. cooperative alliances. Journal of International Business Studies, 27(5), 981-1004.

Johnson, J. L., \& Raven, V. P. (1996). Relationship quality, satisfaction and performance in export marketing channels. Journal of Global Marketing, $5(3 / 4), 19-45$

Johnston, W. J., Lewin, J. E., \& Spekman, R. E. (1999). International industrial marketing interactions: Dyadic and network perspectives. Journal of Business Research, 46(3), 259-271.

Kale, S. H., \& Barnes, J. W. (1992). Understanding the domain of cross-national buyer-seller interactions. Journal of International Business Studies, 23(1), 101-132.

Karanuratna, A. R., \& Johnson, L. W. (1997). Initiating and maintaining export channel intermediary relationships. Journal of International Marketing, 5(2), $11-32$.

Katsikeas, C. S. (1998). Import stimuli and import development. Management International Review, 38(3), 215-237.

Katsikeas, C. S., Leonidou, L. C., \& Morgan, N. A. (2000). Firm-level export performance assessment: Review, evaluation, and development. Journal of the Academy of Marketing Science, 28(4), 493-511.

Kim, K. (2000). On interfirm power, channel climate, and solidarity in industrial distributor-supplier dyads. Journal of the Academy of Marketing Science, 28(3), 388-405.

Kim, K., \& Frazier, G. L. (1997). On distributor commitment in industrial channels of distribution: A multicomponent approach. Psychology and Marketing, 14(8), 847-877.

Klein, S. (1991). Selection of international marketing channels. Journal of Global Marketing, 4(4), 21-37.

Klein, S., Frazier, G., \& Roth, V. J. (1990). A transaction cost analysis model of channel integration in international markets. Journal of Marketing Research, 27(2), 196-208.

Klein, S., \& Roth, V. J. (1990). Determinants of export channel structure: The effects of experience and psychic distance reconsidered. International Marketing Review, 7(5), 27-38.

Kumar, N., Scheer, L. K., \& Steenkamp, J. -B. E. M. (1995). The effects of perceived interdependence on dealer attitudes. Journal of Marketing Research, 32(3), 348-356.

Kumar, N., Stern, L. W., \& Anderson, J. C. (1993). Conducting interorganizational research using key informants. The Academy of Management Journal, 27(4), 24-36.

Lages, C., Lages, C. R., \& Lages, L. F. (2005). The RELQUAL scale: A measure of relationship quality in export market ventures. Journal of Business Research, 58(8), 1040-1048.

Leonidou, L. C. (2003). Overcoming the limits of exporting research using the relational paradigm. International Marketing Review, 20(2), 129-141.

Leonidou, L. C., Barnes, B. R., \& Talias, M. A. (2006). Exporter-importer relationship quality: The inhibiting role of uncertainty, distance, and conflict. Industrial Marketing Management, 35(5), 576-588.

Leonidou, L. C., \& Kaleka, A. A. (1998). Behavioral aspects of international buyer-seller relationships: Their association with export involvement. International Marketing Review, 15(5), 373-397.

Leonidou, L. C., \& Katsikeas, C. S. (1996). The export development process: An integrative review of empirical models. Journal of International Business Studies, 27(3), 517-551.
Levy, D. L. (1997). Lean production in an international supply chain. Sloan Management Review, 38(2), 94-102.

Liang, N., \& Parkhe, A. (1997). Importer behavior: The neglected counterpart of international exchange. Journal of International Business Studies, 28(3), 495-530.

Lin, X., \& Germain, R. (1998). Sustaining satisfactory joint venture relationships: The role of conflict resolution strategy. Journal International Business Studies, 29(1), 179-196.

Lin, X., \& Germain, R. (1999). Predicting international joint venture interaction frequency in U.S.-Chinese ventures. Journal International Marketing, 7(2), $5-23$.

Lohtia, R., Bello, D. C., Yamada, T., \& Gilliland, D. L. (2005). The role of commitment in foreign-Japanese relationships: Mediating performance for foreign sellers in Japan. Journal of Business Research, 58(8), 1009-1018.

Madhok, A. (2006). Revisiting multinational firms' tolerance for joint ventures: A trust-based approach. Journal of International Business Studies, 37(1), $30-43$.

Mehta, R., Larsen, T., Rosenbloom, B., \& Ganitsky, J. (2005). The impact of cultural differences in U.S. business-to-business export marketing channel strategic alliances. Industrial Marketing Management, 35(2), 156-165.

Moorman, C., Zaltman, G., \& Deshpande, R. (1992). Relationships between providers and users of market research: The dynamics of trust within and between organizations. Journal of Marketing Research, 29(3), 314-328.

Morgan, R. M., \& Hunt, S. D. (1994). The commitment-trust theory of relationship marketing. Journal of Marketing, 58(3), 20-38.

Morgan, N. A., Kaleka, A., \& Katsikeas, C. S. (2004). Antecedents of export venture performance: A theoretical model and empirical assessment. Journal of Marketing, 68(1), 90-108.

Naude, P., \& Buttle, F. (2000). Assessing relationship quality. Industrial Marketing Management, 29(4), 351-361

Pfeffer, J., \& Salancik, G. (1978). The external control of organizations: A resource dependence perspective. New York: Harper \& Row Publishers.

Poon, P. S., Evangelista, F. U., \& Albaum, G. (2005). A comparative study of the management styles of marketing managers in Australia and the People's Republic of China. International Marketing Review, 22(1), 34-47.

Quintens, L., Pauwels, P., \& Matthyssens, P. (2006). Global purchasing strategy: Conceptualization and measurement. Industrial Marketing Management, 35(7), 881-891.

Rindfleisch, A., \& Heide, J. B. (1997). Transaction cost analysis: Past, present, and future applications. Journal of Marketing, 61(4), 30-54

Robicheaux, R. A., \& Coleman, J. A. (1994). The structure of marketing channel relationships. Academy of Marketing Science, 22(1), 38-51.

Rokkan, A. I., Heide, J. B., \& Wathne, K. H. (2003). Specific investments in marketing relationships: Expropriation and bonding effects. Journal of Marketing Research, 40(2), 210-224.

Rosenbloom, B., \& Larsen, T. L. (1992). How foreign firms view their U.S. distributors. Industrial Marketing Management, 21(2), 93-101.

Samiee, S., \& Walters, P. G. P. (2003). Relationship marketing in an international context: A literature review. International Business Review, 12(2), 193-214.

Samiee, S., \& Walters, P. G. P. (2006). Supplier and customer exchange in international industrial markets: An integrative perspective. Industrial Marketing Management, 35(5), 589-599.

Sharma, A., \& Sheth, J. N. (1997). Relationship marketing: An agenda for inquiry. Industrial Marketing Management, 26(2), 87-89.

Sheth, J. N., \& Parvatiyar, A. (1995). The evolution of relationship marketing. International Business Review, 4(4), 397-418.

Sheth, J. N., \& Parvatiyar, A. (2001). The antecedents and consequences of integrated global marketing. International Marketing Review, 18(1), 16-29.

Shoham, A., \& Albaum, G. S. (1995). Reducing the impact of barriers to exporting: A managerial perspective. Journal of International Marketing, 3 (4), 85-105.

Shoham, A., Rose, G. M., \& Kropp, F. (1997). Conflict in international channels of distribution. Journal of Global Marketing, 11(2), 5-22.

Skarmeas, D., Katsikeas, C. S., \& Schlegelmilch, B. B. (2002). Drivers of commitment and its impact on performance in cross-cultural buyer-seller relationships: The importer's perspective. Journal of International Business Studies, 33(4), 757-783 
Smith, J. B. (1998). Buyer-seller relationships: Similarity, relationship management, and quality. Psychology and Marketing, 24(1), 18-34.

Sousa, C. M. P., \& Bradley, F. (2006). Cultural distance and psychic distance: Two peas in a pod? Journal of International Marketing, 14(1), 49-70.

Stern, L. W., \& Reve, T. (1980). Distribution channels as political economies: A framework for comparative analysis. Journal of Marketing, 44(3), 52-64.

Stottinger, B., \& Schlegelmich, B. B. (1998). Explaining export development through psychic distance: Enlightening or elusive? International Marketing Review, 15(5), 357-372.

Stottinger, B., \& Schlegelmilch, B. B. (2000). Psychic distance: A concept past its due date? International Marketing Review, 17(2), 169-173.

Styles, C., \& Ambler, T. (2000). The impact of relational variables on export performance: An empirical investigation in Australia and the UK. Australian Journal of Management, 25(3), 261-281.

Terpstra, V., \& Sarathy, R. (2000). International marketing. Fort Worth: Dryden Press.

Ulaga, W., \& Eggert, A. (2006). Relationship value and relationship quality: Broadening the nomological network of business-to-business relationships. European Journal of Marketing, 40(3/4), 311-327.

Walter, A., Muller, T. A., Helfert, G., \& Ritter, T. (2003). Functions of industrial supplier relationships and their impact on relationship quality. Industrial Marketing Management, 32(2), 159-169.

Wathne, K. H., Biong, H., \& Heide, J. B. (2001). Choice of supplier in embedded markets: Relationship and marketing program effects. Journal of Marketing, 65(2), 54-66.

Williamson, O. E. (1985). The economic institutions of capitalism. New York: The Free Press.

Zaichkowsky, J. L. (1985). Measuring the involvement construct. Journal of Consumer Research, 12(3), 341-352.

Zhang, C., Cavusgil, S. T., \& Roath, A. S. (2003). Manufacturer governance of foreign distributor relationships: Do relational norms enhance competitiveness in the export market? Journal of International Business Studies, 34(6), $550-556$.
Dionysis Skarmeas is a Lecturer in Marketing at the Department of Industrial Management \& Technology, University of Piraeus, Greece. His research interests lie in the areas of international channels of distribution, exporting, and competitive strategy. His research has appeared in Journal of International Business Studies, Industrial Marketing Management, European Journal of Marketing, and International Marketing Review.

Constantine S. Katsikeas is the Arnold Ziff Research Chair in Marketing and International Management and the Marketing Department Chair at Leeds University Business School, U.K. He is an associate editor of British Journal of Management. His main research interests focus on international marketing and purchasing, competitive strategy, and collaborative exchange relationships. $\mathrm{He}$ has published widely in these fields and articles of his have appeared in Journal of Marketing, Organization Sciences, Strategic Management Journal, Decision Sciences, Journal of International Business Studies, Journal of International Marketing, and other journals.

Stavroula Spyropoulou is an Academic Research Fellow in Marketing at Leeds University Business School, U.K. Her research interests focus on competitive strategy and international marketing. She has published her work in Industrial Marketing Management, International Marketing Review, and British Journal of Management.

Esmail Salehi-Sangari is Chair Professor and Head of the Industrial Marketing and e-Commerce Research Group at Lulea University of Technology, Sweden. His main research interests lie in the fields of industrial marketing and purchasing, e-business and Internet marketing, and marketing strategy. He has published widely in these fields and has engaged in major consulting projects in the public and private sectors and the design and implementation of executive development and training programs in various countries. 